\title{
THE INFLUENCE OF ADDITIVES ON FROZEN SNAKEHEAD FISH SURIMI AND THE APPLICATION OF TRANSGLUTAMINASE TO FISH CAKES
}

\author{
Nguyen Van $\mathrm{Muoi}^{1}$, Tran Thanh Truc ${ }^{1}$, Vo Hoang Ngan ${ }^{2 \bowtie}$ \\ ${ }^{1}$ Can Tho University \\ Campus 2, 3/2 str., Can Tho City, Ninh Kieu District, Vietnam \\ ${ }^{2}$ Food Technology K2015, Department of Science and Technology, Can Tho University \\ 111 Nguyen Hue str., Ward 2, Vinh Long City, Vinh Long Province, Vietnam
}

\begin{abstract}
Background. The co-product of cultured snakehead fish protein extraction is an abundant source of myofibrillar protein, with the potential for application in the processing of frozen snakehead fish surimi. The objective of this study was to determine the influence of additives and incubation time on the quality of surimi and surimi-based products.

Materials and methods. Cryoprotectant (a mixture of sucrose and sorbitol at a ratio of 1:1 changed from $2 \%$ to $4 \%$ ), in combination with sodium tripolyphosphate $(0.1,0.15,0.2$ and $0.25 \%)$, was added to surimi during its preparation. In addition, the study also investigated the ratio of transglutaminase supplementation $(0.5,0.7$ and $0.9 \%)$ and incubation time $(2,4$ and $6 \mathrm{~h})$ in the processing of high-quality fried fish cakes from frozen snakehead fish surimi.

Results. The results showed that, a combination of 3\% cryoprotectant and $0.2 \%$ sodium tripolyphosphate helped maintain the quality of snakehead fish surimi after frozen storage. In the processing of fried fish cakes from frozen snakehead fish surimi, the addition of $0.7 \%$ transglutaminase $(0.28 \mathrm{U} / \mathrm{g}$ surimi) with $4 \mathrm{~h}$ incubation significantly improved the gel properties of the product.

Conclusions. It is necessary to have appropriate additives and incubation time in the processing of surimi and surimi-based products from the co-product of cultured snakehead fish protein extraction.
\end{abstract}

Keywords: cryoprotectant, fish cake, sodium tripolyphosphate, surimi, transglutaminase

\section{INTRODUCTION}

Snakehead fish (Channa striata) have long been known to be a potential source of the proteins required by humans, especially those with poor health. This is due to its adequate supply of fish protein, and its balance of essential and non-essential amino acids
(Mustafa et al., 2013). Surimi is the wet concentrate of the myofibrillar proteins of fish muscle which is light in color, bland in odor and low in fat (Ramadhan et al., 2014). This is an important intermediate product containing stabilized myofibrillar proteins obtained from

Funding Source Declaration. This research project received no specific grant from any funding agency in the public, commercial, or not-for-profit sectors. It was performed as part of the employment of the author (Nguyen Van Muoi and Vo Hoang Ngan). 
minced fish that is washed to remove blood, pigments, lipids, enzymes and sarcoplasmic protein, blended with cryoprotectants and sodium tripolyphosphate (STPP), and then used in the production of fabricated fish-based products (Balange and Benjakul, 2009; Wu, 2016). Snakehead fish is a popular fish in Vietnam, especially in Vinh Long, but its price is very low. The coproduct of cultured snakehead fish protein extraction is an abundant source of myofibrillar protein (Vo et al., 2017). It possesses some important functional properties, such as gel-forming abilities and water holding capacities, which provide the potential for application in the processing of surimi. Luo et al. (2001) reported that the surimi from freshwater fish species is inferior marine species in terms of gel properties. However, Nousad et al. (1999) observed that surimi from tropical freshwater fish species, for example snakehead fish, wild mullet and Nile tilapia, showed good gel setting abilities. Hultin and Kelleher (2000) also used an alkaline solution to obtain surimi of a better quality, particularly a high gel strength, white color and the right flavor.

Transglutaminase is an enzyme isolated from a variant of Streptomyces mobaraensis that forms covalent cross-links between protein molecules (Ramadhan et al., 2014). The application of transglutaminase has created new technological opportunities for producing good fish cakes, even from poor quality fish muscle. Therefore, the aim of the study was to determine the effectiveness of the addition of cryoprotectant and STPP to maintain the gel quality of snakehead fish surimi after freezing and frozen storage. In addition, the study also investigated the ratio of transglutaminase supplementation and the incubation time in the processing of high-quality fried fish cakes from frozen snakehead fish surimi.

\section{MATERIALS AND METHODS}

The research was conducted at the Laboratory of Food Technology, Faculty of Agriculture and Applied Biology, Can Tho University. Major equipment and chemicals used in the study include Planimeter (Germany), Colorimeter NH300 (China), Rheotex SD305 (Japan).

Activa TG-SR-MH with transglutaminase activity of $40 \mathrm{U} / \mathrm{g}$ was used for this research (Determined according to Oteng-Pabi and Keillor, 2013).
Cultured snakehead fish (with average weight from $400 €-700 \mathrm{~g}$ ) was purchased directly from the farming area in Vinh Long province, Vietnam. After collection, the fish was transported live (in a bucket of water) to the laboratory, which took about $1 \mathrm{~h}$. At the laboratory, the live fish was kept stable in the water tank for at least $1 \mathrm{~h}$ before further processing.

\section{Sample preparation}

Snakehead fish were weighed prior to preliminary processing. The fish was stunned, cut and its blood was discharged into the water tank. After the blood had been drained, the fins, skin, viscera and head were removed, and the fish was washed in $0.5 \% \mathrm{NaCl}$ solution. After preliminary processing, the fillet was taken and washed with water at a low temperature $\left(5-10^{\circ} \mathrm{C}\right)$. The fillets were then cut into $2 \times 2 \mathrm{~cm}$ pieces and packed into PE bags $(1 \mathrm{~kg} / \mathrm{bag})$ for freezing at -18 $\pm 2{ }^{\circ} \mathrm{C}$. The fish meat had to be stored frozen at least $24 \mathrm{~h}$ before studying to help stabilize and regulate the material source and make it easy to cut afterwards.

\section{Research procedures}

The frozen fish meat was cut evenly $(<5 \mathrm{~mm})$ before washing to recover myofibrillar protein by heated magnetic stirring. One washing cycle was performed with $\mathrm{NaCl} 0.15 \mathrm{M}$ solution, with a 1:2 ratio of minced fish and solvent at $35^{\circ} \mathrm{C}$ for $14 \mathrm{~min}$ to remove soluble protein and other soluble components, according to Vo et al. (2017). The wash mixture was compressed through a filter cloth to separate the fluid and recover the fish paste with a moisture content of less than $78 \%$. The recovered fish paste was mixed with sugar, sorbitol and tripolyphosphate (experiment 1) to form surimi. The moisture content of the surimi was adjusted to $76 \%$ with ice. The final surimi was put into frozen storage for at least $24 \mathrm{~h}$ before conducting the next study. The frozen surimi was roughly cut to break down the structure while simultaneously mixing transglutaminase according to the study in experiment 2. The fixed additive and spices of $\mathrm{NaCl}$, modified starch, pepper, garlic powder, monosodium glutamate and ice were $1.32 \%, 3 \%, 0.5 \%, 0.5 \%, 0.3 \%$ and $6.17 \%$, respectively (Nguyen and Dang, 2003; Vo et al., 2018). The surimi were finely cut to create a paste before forming a disk shape $(70 \times 15 \mathrm{~mm})$. The sample was kept in a refrigerator at $4 \pm 2{ }^{\circ} \mathrm{C}$ with the 
incubation time in experiment 2 before being presteamed at $80-85^{\circ} \mathrm{C}$ until the central temperature of the product rose to $55^{\circ} \mathrm{C}$. The pre-steamed fish cake would be cooled to $2-4^{\circ} \mathrm{C}$ in a refrigerator for at least $24 \mathrm{~h}$ before deep frying at $180^{\circ} \mathrm{C}$ for $3 \mathrm{~min}$. An analysis of fried fish cake parameters was carried out after keeping the sample in a refrigerator for at least $24 \mathrm{~h}$. The result of experiment 1 was chosen as a fixed factor for experiment 2.

Experiment 1. Investigated the effects of cryoprotectant (mixture of sucrose and sorbitol at ratio of 1:1 changing from $2 \%$ to $4 \%$ ) in combination with STPP $(0.1,0.15,0.2$ and $0.25 \%)$ on the quality of frozen snakehead fish surimi.

Experiment 2. Investigated the ratio of transglutaminase (TGase) supplementation $(0.5,0.7,0.9 \%$; corresponding to TGAse activity changed from $0.20,0.28$ and $0.36 \mathrm{U} / \mathrm{g}$ surimi) and incubation time $(2,4,6 \mathrm{~h})$ in the processing of high-quality fried fish cakes from frozen snakehead fish surimi. Other additives were fixed as a result of experiment 1 .

\section{Proximate analysis}

The proximate analysis was determined according to AOAC methods (AOAC, 1995), the moisture content was determined by AOAC 925.04 , the protein content by the Kjeldahl method (AOAC 981.10) and the lipid content by the Soxhlet method (AOAC 920.39). The Water holding capacity (WHC) of the fish samples was determined by using the filter paper press method (FPPM; Muhlisin et al., 2012) with approximately $0.3 \mathrm{~g}$ of fish sample being placed between two filter papers and an amount of weight $(1 \mathrm{~kg})$ put on it to compress the fish for $10 \mathrm{~min}$. The amount of water expressed to the filter paper due to the compression was indicated by the areas of the purge on the filter paper, which can be measured using a planemeter. Gel strength (GS) was measured using a Rheometer on a cylindrical fish cake $(10 \times 12 \mathrm{~mm})$ (Nowsad et al., 2000). Whiteness (WI $=L^{*}-3 b^{*}$ ) was measured using a Colorimeter NH300 (Luo et al., 2004).

\section{Data analysis}

Using Statgraphics Centurion 16.1 program, data were analyzed for the degree of variation and significance of difference based on the analysis of variance (ANOVA) to determine if significant differences $(p \leq 0.05)$ existed between treatments using the least significant difference (LSD) or Duncan test. All experiments were carried out in triplicate.

\section{RESULTS AND DISCUSSIONS}

\section{Physical and chemical properties of snakehead fish muscle}

Snakehead fish from Vinh Long province was used as a raw material for all experiments. The snakehead fish muscle (fillet, paste) was analyzed after each treatment to determine its basic chemical and physical properties (Table 1).

Table 1. Chemical and physical properties of cultured snakehead fish muscle

\begin{tabular}{lrr}
\hline \multicolumn{1}{c}{ Proximate parameters } & \multicolumn{1}{c}{ Fillet } & \multicolumn{1}{c}{ Paste } \\
\hline Moisture, \% & $77.44^{\mathrm{a}} \pm 0.42$ & $78.47^{\mathrm{b}} \pm 0.31$ \\
Protein, \% & $18.52^{\mathrm{b}} \pm 0.29$ & $16.75^{\mathrm{a}} \pm 0.49$ \\
Lipid, \% & $2.63^{\mathrm{b}} \pm 0.11$ & $2.02^{\mathrm{a}} \pm 0.13$ \\
WHC, \% & $67.95^{\mathrm{a}} \pm 0.28$ & $69.97^{\mathrm{b}} \pm 0.36$ \\
pH & $6.77^{\mathrm{a}} \pm 0.06$ & $6.83^{\mathrm{a}} \pm 0.06$ \\
Muscle recovery efficiency, \% & $46.05 \pm 1.63$ & $70.16 \pm 0.64^{*}$ \\
\hline
\end{tabular}

Different letters in a row indicate significant differences in the test treatments at $95 \%$ confidence intervals.

*Calculated according to the amount of fish fillet.

The results also showed that washing increased the water holding capacity of the fish muscle compared to raw fish fillet, as it reached $69.97 \%$. This may have been due to the washing process that removed soluble proteins, lipids $(2.02 \%)$ and other components from the fish muscle, increasing the muscle myofibrillar protein concentration in the paste (Chaijan et al., 2004). However, the loss of soluble proteins and the fact that the moisture content of the fish paste was maintained at a higher level than that of the fish fillet resulted in the protein content of the paste decreasing to $16.75 \%$. The removal of the sarcoplasmic protein, lipids and pigments, as well as the $\mathrm{pH}$ of the fish paste 
being maintained at a high level ( $\mathrm{pH} 6.83)$ by washing with $0.15 \mathrm{M} \mathrm{NaCl}$ solution ( $\mathrm{pH} 10$ ), improved the gel formation of the fish paste (Balange and Benjakul, 2009). In addition, the low fluctuation of the raw material index (less than $2 \%$ ) showed that the uniformity of the material sources had been guaranteed. All of this showed that the washed snakehead fish paste was suitable for processing protein-based products (surimi or fish cakes) but also that it required appropriate solutions to maintain and enhance the gel properties of the product.

\section{The effects of cryoprotectant in combination with STPP on the quality of frozen fish surimi}

In the technology of frozen surimi processing, STPP and cryoprotectant have played a key role in maintaining product quality by protecting the structure and the functions of proteins. In the study, an evaluation of the effects of these two additives on the quality of frozen surimi was done using fish cakes processed from surimi after one week of frozen storage. Table 2 shows that the addition of cryoprotectant ( $2 \%$ to $4 \%$ ) and
STPP $(0.1 \%$ to $0.25 \%)$ had a significant effect on the quality of frozen surimi. This influence is reflected by changes in the gel properties of fried fish cakes.

The results showed that low supplementation rates of additives ( $2 \%$ of cryoprotectant, 0.1 or $0.15 \%$ STPP) resulted in the lowest gel quality. Research results have also confirmed that it is necessary to increase the rate of addition of additives to improve the quality of frozen surimi. According to Arakawa and Timasheff (1982), the supplementation of cryoprotectant to increase water surface tension and binding energy, prevents the separation of water from proteins, thereby stabilizing the protein of the product. However, the results of Table 2 and Figure 1 showed that the addition rate of the additives was too high ( $4 \%$ cryoprotectant and $0.25 \%$ STPP) to disrupt the gel system of the product (water holding capacity and gel strength decrease). This can be explained by the presence of large proportions of additives that reduce the protein concentration in the gel system (Luo et al., 2001). Therefore, it can be concluded that the addition of $3 \%$ cryoprotectant combined with $0.25 \%$ STPP is suitable

Table 2. The effects of cryoprotectant in combination with STPP on the quality of fried fish cakes processed from frozen snakehead fish surimi

\begin{tabular}{cccc}
\hline Cryoprotectant, $\%$ & STPP, $\%$ & Whiteness & Gel strength, $\mathrm{kg}_{\mathrm{f}} \times \mathrm{mm}$ \\
\hline 2 & 0.10 & $40.11^{\mathrm{ab}} \pm 0.13$ & $3.61^{\mathrm{cd}} \pm 0.13$ \\
0.15 & $40.05^{\mathrm{ab}} \pm 0.26$ & $3.87^{\mathrm{de}} \pm 0.19$ \\
0.20 & $40.73^{\mathrm{b}} \pm 0.83$ & $3.94^{\mathrm{def}} \pm 0.20$ \\
0.25 & $39.56 \mathrm{a} \pm 0.68$ & $4.02^{\text {ef }} \pm 0.24$ \\
0.10 & $43.15^{\mathrm{c}} \pm 0.32$ & $3.86^{\mathrm{de}} \pm 0.26$ \\
3 & 0.15 & $42.57^{\mathrm{c}} \pm 0.32$ & $3.69^{\mathrm{cde}} \pm 0.16$ \\
& 0.20 & $43.50^{\mathrm{cd}} \pm 0.58$ & $4.40^{\mathrm{g}} \pm 0.11$ \\
& 0.25 & $44.13^{\mathrm{d}} \pm 0.93$ & $4.28^{\mathrm{fg}} \pm 0.29$ \\
& 0.10 & $42.72^{\mathrm{c}} \pm 0.74$ & $3.40^{\mathrm{bc}} \pm 0.12$ \\
& 0.15 & $42.54^{\mathrm{c}} \pm 0.31$ & $3.43^{\mathrm{bc}} \pm 0.19$ \\
& 0.20 & $40.93^{\mathrm{b}} \pm 0.51$ & $2.88^{\mathrm{a}} \pm 0.22$ \\
& 0.25 & $40.09^{\mathrm{ab}} \pm 0.31$ & $3.12^{\mathrm{ab}} \pm 0.18$ \\
\hline
\end{tabular}

Different letters in a row indicate significant differences in the test treatments at $95 \%$ confidence intervals. 
Van Muoi, N., Thanh Truc, T., Hoang Ngan, V. (2019). The influence of additives on frozen snakehead fish surimi and the application of transglutaminase to fish cakes. Acta Sci. Pol. Technol. Aliment., 18(2), 125-133. http://dx.doi.org/10.17306/J.AFS.2019.0636

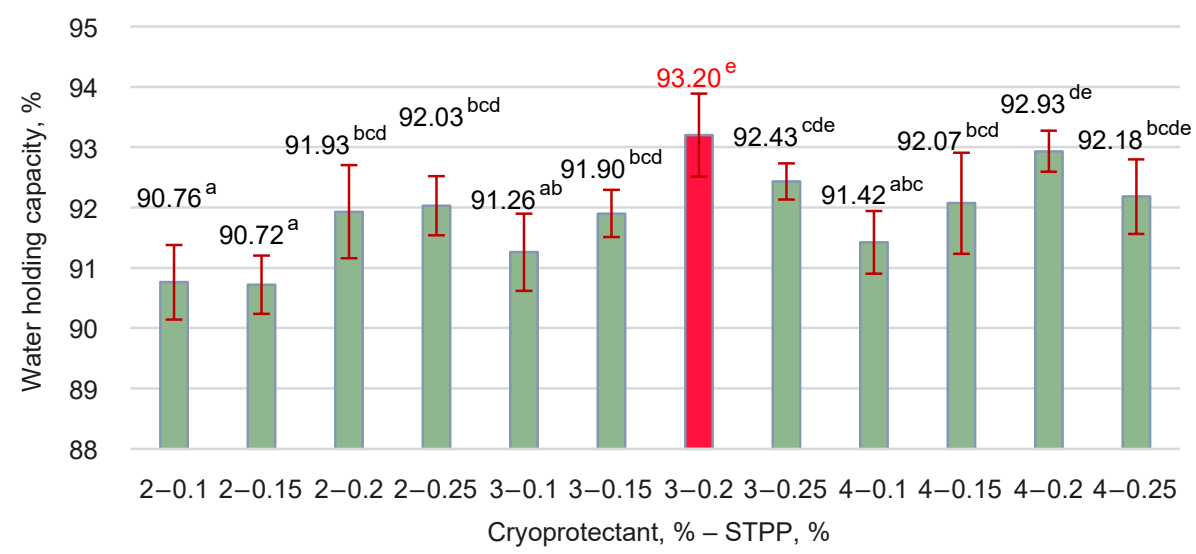

Fig. 1. The effects of cryoprotectant in combination with STPP on the water holding capacity of fried fish cakes processed from frozen snakehead fish surimi

for high gel strength. The difference was not statistically significant when the STPP supplementation rate was $0.25 \%$.

The results of Figure 1 also showed that increasing the rate of supplementation of STPP helped to increase the water holding capacity of the fried fish cake product. However, there was no statistically significant difference when increasing the STPP supplement rate to $0.25 \%$. With the same results, Girard (1992) suggested that the addition of polyphosphate would help the formation of bonds with $\mathrm{Ca}^{2+}, \mathrm{Mg}^{2+}$, which would allow the protein network to loosen, thereby increasing its ability to bind to water. Figure 1 also showed that the combination of $3 \%$ cryoprotectant and $0.2 \%$ STPP was appropriate to improve the water holding capacity of fried fish cakes. In addition, snakehead fish surimi with an addition rate of $3 \%$ cryoprotectant combined with $0.2 \%$ or $0.25 \%$ STPP gave the product a high whiteness (Table 2).

In conclusion, the supplementation of cryoprotectant and STPP in the processing of frozen snakehead fish surimi showed that the addition rate of $3 \%$ of cryoprotectant and $0.2 \%$ of STPP was appropriate. At this rate of supplementation, the product processed from frozen surimi had an improved water holding capacity, gel strength and whiteness. The result was similar to that of Yoo (2014) in the selection of 3\% sorbitol and $0.2 \%$ STPP for the processing of frozen surimi from Pacific Sand Lance.
The role of transglutaminase supplementation and incubation time in the processing of high-quality fried fish cakes from frozen snakehead fish surimi

The gel-forming process involves cross-linking between myosin chains that are catalyzed by the intracellular transglutaminase. Reactions catalysed by transglutaminase result in significant changes in the physicochemical properties of gel, such as changes in viscosity, thermal stability and elasticity. Yongsawatdigul et al. (2002) investigated the residual transglutaminase activity in threadfin bream surimi wash water, confirming that $44 \%$ of the original transglutaminase activity remained in the final surimi after the washing process (Seighalani et al., 2017). All this has shown the need for transglutaminase supplementation during protein gel formation from fish surimi. In addition, the incubation time also plays an important role in promoting the effectiveness of this enzyme during processing. Therefore, the study was conducted on the rate of transglutaminase addition and incubation time to improve the gel quality of the surimi-based product, as shown in Table 3 and Figure 2.

Table 3 showed that different ratios of transglutaminase have a significant effect on the whiteness of the product, which increased with an increase in the ratio of transglutaminase. However, the difference was not statistically significant when the transglutaminase supplementation rate was $0.9 \%$ (or $0.36 \mathrm{U} / \mathrm{g}$ surimi). 
Van Muoi, N., Thanh Truc, T., Hoang Ngan, V. (2019). The influence of additives on frozen snakehead fish surimi and the application of transglutaminase to fish cakes. Acta Sci. Pol. Technol. Aliment., 18(2), 125-133. http://dx.doi.org/10.17306/J.AFS.2019.0636

Table 3. The effects of incubation time and transglutaminase on whiteness, WHC of snakehead fish cakes

\begin{tabular}{ccccc}
\hline \multirow{2}{*}{ Incubation time, $\mathrm{h}$} & \multicolumn{2}{c}{ Transglutaminase } & Whiteness & WHC, \% \\
\cline { 2 - 3 } 2 & \% surimi & U/g surimi & & \\
\cline { 1 - 2 } 2 & 0.5 & 0.20 & $42.63^{\mathrm{bcd}} \pm 0.37$ & $90.70^{\mathrm{ab}} \pm 0.36$ \\
& 0.9 & 0.28 & $43.33^{\mathrm{de}} \pm 0.29$ & $93.43^{\mathrm{d}} \pm 0.60$ \\
& 0.5 & 0.36 & $43.71^{\mathrm{e}} \pm 0.42$ & $91.33^{\mathrm{b}} \pm 0.37$ \\
& 0.7 & 0.20 & $41.94^{\mathrm{b}} \pm 0.51$ & $91.16^{\mathrm{b}} \pm 0.27$ \\
& 0.9 & 0.28 & $40.06^{\mathrm{cde}} \pm 0.54$ & $94.70^{\mathrm{e}} \pm 0.36$ \\
& 0.5 & 0.36 & $43.22^{\mathrm{cde}} \pm 0.37$ & $93.46^{\mathrm{d}} \pm 0.34$ \\
& 0.7 & 0.20 & $40.99^{\mathrm{a}} \pm 0.52$ & $90.61^{\mathrm{ab}} \pm 0.62$ \\
& 0.9 & 0.28 & $42.47^{\mathrm{bc}} \pm 0.48$ & $90.34^{\mathrm{a}} \pm 0.30$ \\
& 0.36 & $43.01^{\text {cde }} \pm 0.28$ & $92.38^{\mathrm{c}} \pm 0.44$ \\
\hline
\end{tabular}

Different letters in a row indicate significant differences in the test treatments at $95 \%$ confidence intervals.

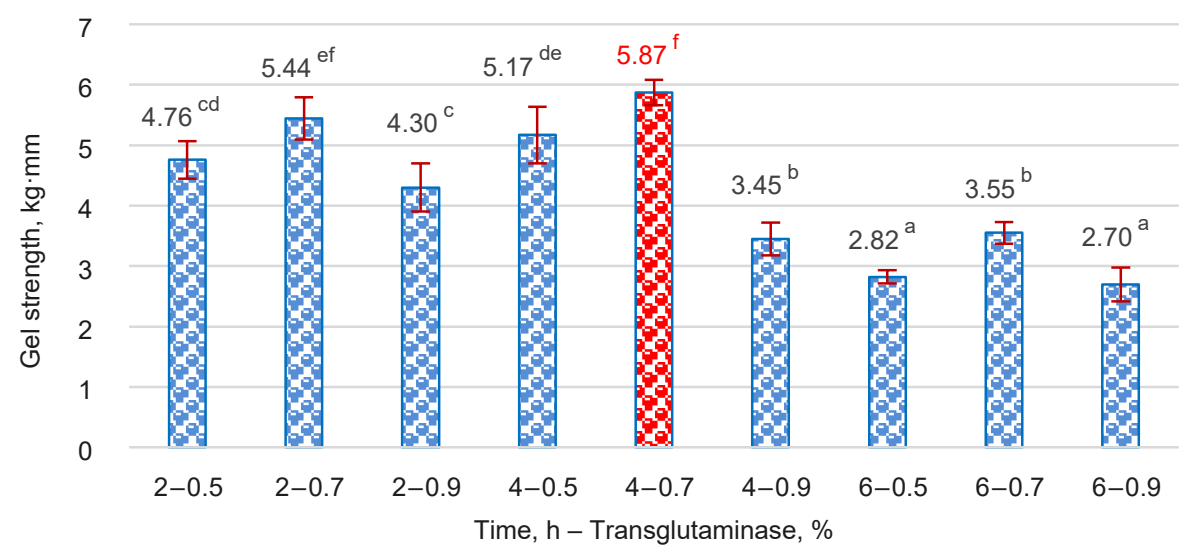

Fig. 2. The effects of incubation time and transglutaminase on gel strength of fried fish cakes

The results of the study also showed that the whiteness of the product was high for a short incubation time and a high ratio of transglutaminase (highest whiteness with $0.9 \%$ transglutaminase and $2 \mathrm{~h}$ incubation). This result was similar to that of Karayannakidis et al. (2008), who observed that transglutaminase supplementation improved the whiteness of the gel product from sardine proteins.

The study by Seighalani et al. (2017), and Duangmal and Taluengphol (2010) also showed similar results with transglutaminase supplementation at $0.3 \mathrm{U} / \mathrm{g}$ surimi and $3 \mathrm{~g} / \mathrm{kg}$ surimi, respectively. As transglutaminase catalyzes the cross-linking reaction of myosin and leads to the formation of protein intra- and intermolecular covalent bonds, it was concluded that differences in the whiteness value could correspond to the increased turbidity of gels because of transglutaminase activity. Moreover, an increase in whiteness could be caused by other compounds (lactose, maltodextrin) in commercial transglutaminase 
Van Muoi, N., Thanh Truc, T., Hoang Ngan, V. (2019). The influence of additives on frozen snakehead fish surimi and the application of transglutaminase to fish cakes. Acta Sci. Pol. Technol. Aliment., 18(2), 125-133. http://dx.doi.org/10.17306/J.AFS.2019.0636

powder, which cause a light scattering effect, as shown by Seighalani et al. (2017). Besides whiteness, the water holding capacity and gel strength are also important indicators in evaluating fried fish cake quality. Table 3 and Figure 2 show that the water holding capacity and gel strength of the product is significantly affected by the incubation time and the supplementation rate of transglutaminase.

At the appropriate level of incubation time and transglutaminase, the product had the best water holding capacity and gel strength. An increase or decrease of these levels has no positive impact on product quality. This is explained by the effect of transglutaminase, which helps the protein gel to be firmer. The stronger protein gel network was possibly linked to its capacity to hold water. However, transglutaminase can also increase protein to protein interactions, leading to a decrease in protein to water interactions. Therefore, the water holding capacity of gels can decrease when high concentrations of transglutaminase are used (Kaewudom et al., 2013). Figure 2 show that the water holding capacity of fried fish cakes was highest at $4 \mathrm{~h}$ of incubation and $0.7 \%$ transglutaminase (average activity was $0.28 \mathrm{U} / \mathrm{g}$ surimi). At this incubation time and supplementation rate of transglutaminase, the product is statistically different from the other combinations. The results are consistent with the publication of Chaijan and Panpipat (2010) on the effect of transglutaminase on the gelatin formation of mackerel protein (Rastrelliger branchysoma). This study indicated that the gel strength of the product increased with the addition of transglutaminase to $0.25 \mathrm{U} / \mathrm{g}$ surimi. The decrease in gel strength of the product with a high transglutaminase supplementation may be explained by the excessive formation of cross-linkages, which lower the gel strength through impeding intermolecular aggregation that reduces formation of formation the gel network (Jongjareonrak et al., 2006).

Figure 2 showed that the incubation time also had a significant effect on the gel strength of the fried fish cakes processed from frozen snakehead fish surimi. Increasing the incubation time from $2 \mathrm{~h}$ to $4 \mathrm{~h}$ significantly increases the gel strength of the product. However, if the incubation time is increased up to $6 \mathrm{~h}$, there is a rapid decline in the gel strength of the product. At the same time, the results have also shown that increasing the rate of excess transglutaminase results in a breakdown of the gel structure of the product. These results are in accord with those obtained by Jiang et al. (2000) who reported that the gel structure of surimi gels from threadfin bream (Nemipterus virgatus) and pollock (Rastrelliger kanagurta) increased when transglutaminase increased up to a certain level, and a further increase in transglutaminase decreased the gel structure of the product (Seighalani et al., 2017).

From the above results, the combination of $4 \mathrm{~h}$ incubation time and $0.7 \%$ commercial transglutaminase (or $0.28 \mathrm{U} / \mathrm{g}$ of surimi) was the most appropriate condition for fish cake processing from frozen surimi. With the combination of these two factors, fried fish cakes made from frozen snakehead fish surimi had the best whiteness, water holding capacity and gel strength.

The results of the SEM also showed the effectiveness of transglutaminase in improving the structure and water holding capacity of the product (Fig. 3). The images showed that fried fish cakes processed from fish fillet had a bad structure and poor water holding capacity because the water was not distributed evenly
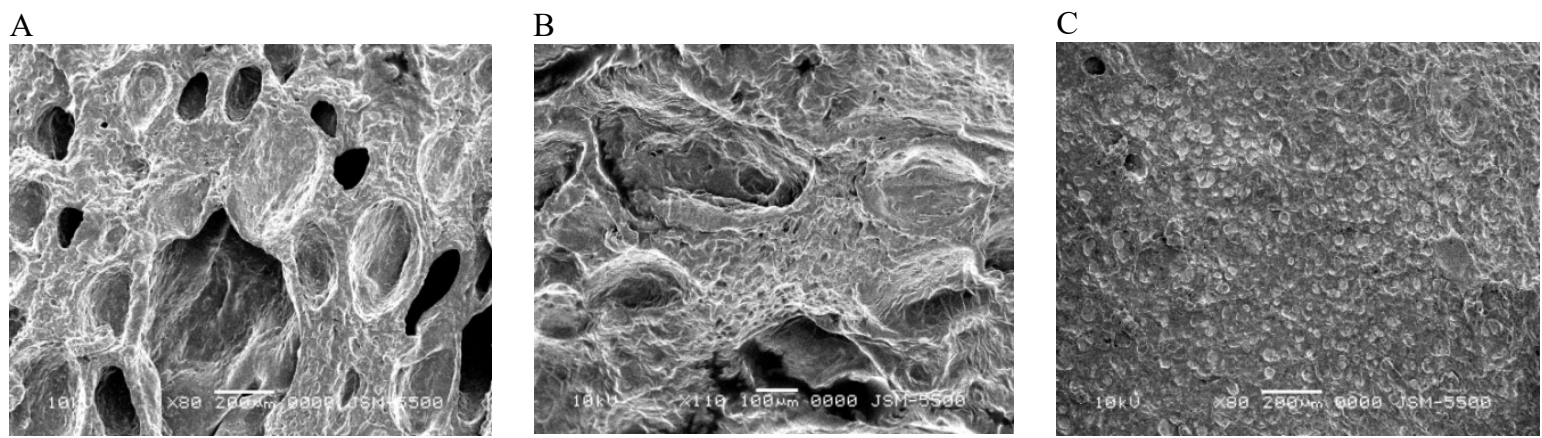

Fig. 3. Scanning electronic micrographs of fried fish cakes processed from different materials: A - fillet, B - surimi, $\mathrm{C}$ - surimi with $0.7 \%$ transglutaminase and $4 \mathrm{~h}$ incubation 
inside the product. In this product, the water had gathered and formed large holes which were found to be smaller for the surimi origin (Fig. 3A, 3B). Figure 3C shows that, with the participation of $0.7 \%$ transglutaminase in combination with a $4 \mathrm{~h}$ incubation time, the surface structure of the product was uniform, and the water dispersed and was retained evenly over all parts of the product. As a result, the structure and water retention capacity of the product was significantly improved.

\section{CONCLUSIONS}

The results of the study showed the feasibility of using the paste of snakehead fish protein (co-product of soluble protein extraction) for processing frozen surimi. The combination of $3 \%$ cryoprotectant $(1.5 \%$ sorbitol and $1.5 \%$ sucrose) and $0.2 \%$ STPP helped to maintain the quality of frozen snakehead fish surimi. In addition, the combination of $0.7 \%$ transglutaminase (or $0.28 \mathrm{U} / \mathrm{g}$ surimi) with $4 \mathrm{~h}$ of incubation in the processing of fried fish cakes significantly improved the gel properties of the product from frozen snakehead fish surimi.

\section{REFERENCES}

AOAC (1995). Official methods of analysis. 15th ed. Washington, DC, USA: Association of Official Analytical Chemist.

Arakawa, T., Timasheff, S. N. (1982). Stabilization of protein structure by sugar. Biochemistry, 21, 6536-6544. https://doi.org/10.1021/bi00268a033

Balange, A. K., Benjakul, S. (2009). Effect of oxidised tannic acid on the gel properties of mackerel (Rastrelliger kanagurta) mince and surimi prepared by different washing processes. Food Hydrocolloids, 23,1693-1701. https://doi.org/10.1016/j.foodhyd.2009.01.007

Chaijan, M., Benjakul, S., Visessanguan, W., Faustman, C. (2004). Characteristics and gel properties of muscles from sardine (Sardinella gibbosa) and mackerel (Rastrelliger kanagurta) caught in Thailand. Food Res. Int., 37, 1021-1030. https://doi.org/10.1016/j. foodres.2004.06.012

Chaijan, M., Panpipat, W. (2010). Gel-forming ability of mackerel (Rastrelliger branchysoma) protein isolate as affected by microbial transglutaminase. Walailak J. Sci. Tech., 7, 41-49.
Duangmal, K., Taluengphol, A. (2010). Effect of protein additives, sodium ascorbate, and microbial transglutaminase on the texture and colour of red tilapia surimi gel. Int. J. Food Sci. Technol., 45(1), 48-55. https://doi. org/10.1111/j.1365-2621.2009.02102.x

Girard, J. B. (1992). Technology of meat and meat products. New York: Ellis Horwood.

Hultin, H. O., Kelleher, S. D. (2000). High efficiency alkaline protein extraction (pp. 136-959). U.S. Patent 6,136,959. Oct. 24, 2000.

Jiang, S. T., Hsieh, J. F., Ho, M. L., Chung, Y. C. (2000). Microbial transglutaminase affects gel properties of golden threadfin-bream and pollack surimi. J. Food Sci., 65, 694-699. https://doi.org/10.1111/j.1365-2621.2000. tb16074.x

Jongjareonrak, A., Benjakul, S., Visessanguan, W., Prodpran, T., Tanaka, M. (2006). Characterization of edible films from skin gelatin of brown stripe red snapper and bigeye snapper. Food Hydrocolloid., 20, 492-501. https://doi. org/10.1016/j.foodhyd.2005.04.007

Kaewudom, P., Benjakul, S., Kijroongrojana, K. (2013). Properties of surimi gel as influenced by fish gelatin and microbial transglutaminase. Food Biosci., 1, 39-47. https://doi.org/10.1016/j.fbio.2013.03.001

Karayannakidis, P. D., Zotos, A., Petridis, D., Taylor, K. D. A. (2008). The effect of washing, microbial transglutaminase, salts and starch addition on the functional properties of Sardine kamaboko gels. Food Sci. Technol. Int., 14, 167-177. https://doi.org/10.1177/1082013208092816

Luo, Y. K., Kuwahara, R., Kaneniwa, M., Murata, Y., Yokoyama, M. (2001). Comparison of gel properties of surimi from Alaska pollock and three freshwater fish species: Effects of thermal processing and protein concentration. J. Food Sci., 66(3), 548-554. https://doi. org/10.1111/j.1365-2621.2001.tb04600.x

Luo, Y. K., Kuwahara, R., Kaneniwa, M., Murata, Y., Yokoyama, M. (2004). Effect of soy protein isolate on gel properties of Alaska pollock and common carp surimi at different setting conditions. J. Sci. Food Agric., 84(7), 663-71. https://doi.org/10.1002/jsfa.1727

Muhlisin, M., Kang, S. M., Choi, W. H., Kim, C. J., An, B. K., ..., Lee, S. K. (2012). New approach to Chuncheon Dakgalbi processing by various chicken materials. Seasoning and cooking methods. Korean J. Food Sci. An., 32(6), 740-748. https://doi.org/10.5851/ kosfa.2012.32.6.740

Mustafa, A., Sujuti, H., Permatasari, N., Widodo, M. A. (2013). Determination of nutrient contents and amino acid composition of Pasuruan Channa striata extract. IEESE Int. J. Sci. Technol., 2(40), 1-11. 
Van Muoi, N., Thanh Truc, T., Hoang Ngan, V. (2019). The influence of additives on frozen snakehead fish surimi and the application of transglutaminase to fish cakes. Acta Sci. Pol. Technol. Aliment., 18(2), 125-133. http://dx.doi.org/10.17306/J.AFS.2019.0636

Nguyen, V. M., Dang, T. T. N. (2003). Apply gel properties of protein in processing fish ball from abundant raw material in Mekong delta: pangas catfish (Pangasius hypophthalamus). In Proceedings in "8th Asean Food Conference” (pp. 96-103). October 8-11, 2003. Hanoi, Vietnam.

Nousad, A. A. K. M., Khan, A. H., Niwa, A. E. (1999). Five tropical fish species: Setting ability and other characteristics of minces. Asian Fish. Sci. J., 12(2), 175-186.

Nowsad, A. A., Kanoh, S., Niwa, E. (2000). Measurement of elastic properties of kamaboko and other food gels by a new simplified rheometer. Asian Fish. Sci. J., 13, $65-73$.

Oteng-Pabi, S. K., Keillor, J. W. (2013). Continuous enzyme-coupled assay for microbial transglutaminase activity. Anal. Biochem., 441(2), 169-173. https://doi. org/10.1016/j.ab.2013.07.014

Ramadhan, K., Huda, N., Ahmad, R. (2014). Effect of number and washing solutions on functional properties of surimi-like material from duck meat. J. Food Sci. Technol., 51(2), 256-266. https://doi.org/10.1007/ s13197-011-0510-1

Seighalani, F. Z. B., Bakar, J., Saari, N., Khoddami, A. (2017). Thermal and physicochemical properties of red tilapia (Oreochromis niloticus) surimi gel as affected by microbial transglutaminase. Anim. Prod. Sci., 57, $993-$ 1000. http://dx.doi.org/10.1071/AN15633
Vo, H. N., Tran, T. T., Nguyen, V. M. (2017). An exploration of the factors affecting the soluble protein extraction from cultured snakehead fish (Channa striata) muscle. J. Sci. Technol. Vietnam, 55(5A), 74-82. https://doi. org/10.15625/2525-2518/55/5A/12181

Vo, H. N., Tran, T. T., Nguyen, V. M. (2018). Optimization of salt - water suplementation combined with other additives to improve the quality of snakehead fish cake. In Proceedings "The 3rd International Conference on Sustainable Global Agriculture and Food (November 2018; pp. 296-310). Vietnam: HCMC.

$\mathrm{Wu}, \mathrm{S}$. (2016). Effect of trehalose on the state of water, protein denaturation and gel-forming ability of weever surimi. Int. J. Food Prop., 19, 521-525. https://doi.org/1 $0.1080 / 10942912.2015 .1033550$

Yongsawatdigul, J., Worratao, A., Park, J. W. (2002). Effect of endogenous transglutaminase on threadfin bream surimi gelation. J. Food Sci., 67, 3258-3263. https://doi. org/10.1111/j.1365-2621.2002.tb09575.x

Yoo, B. J. (2014). The effect of cryoprotectants on the properties of Pacific Sand Lance Ammodytes personatus Girard surimi during frozen storage. Fish. Aquat. Sci., 17(3), 291-298. http://dx.doi.org/10.5657/ FAS.2014.0291 